\title{
Stability-Indicating RP-HPLC Method for the Quantification of Paliperidone in Bulk and Solid Dosage Form to Establish Validation and Stability Indicating Parameters
}

\author{
Sadashivaiah Rudragangaiah, Rohith Ganapathi Bhatta, Satheesha Babu Birur Kotappa* \\ Department of Pharmaceutics, Government College of Pharmacy, P Kalinga Rao Road, Subbaiah Circle, Bengaluru, Karnataka, INDIA.
}

\begin{abstract}
Objectives: In the present research work, stability indicating reverse phase high performance liquid chromatography method was developed and validated for the quantification of paliperidone in bulk and solid dosage form. Materials and Methods: The chromatographic separation of paliperidone was carried out using Phenomenex, Gemini $\mathrm{NX}$, Octadecyl silane column $(150 \times 4.6 \mathrm{~mm}, 5 \mu \mathrm{m}$, particle size) with the mobile phase consisting of methanol: acetonitrile: $0.15 \% \mathrm{v} / \mathrm{v}$ triethylamine in water $(\mathrm{pH} 6)$ in the ratio of 50:20:30 v/v, flow rate was determined at $1 \mathrm{ml} / \mathrm{min}$. UV detection wavelength was observed at $237 \mathrm{~nm}$. Method validation and stress testing was carried out as per $\mathrm{ICH}$ guidelines Q2 (R1) and Q1A (R2) to demonstrate the suitability and specificity of the method. Results: The developed method had shorter retention time of $3.2 \mathrm{~min}$. The RSD for system, method and intermediate precision in all instrumental condition was found to be less than $2 \%$ and the mean recovery was found to be $100.64 \%$. Linearity range was obtained at concentration range of $7.5-150 \mu \mathrm{g} / \mathrm{ml}$ with a regression coefficient $\left(R^{2}\right)$ of 0.999 . Detection and quantification limits for paliperidone were found to be 0.14 and $0.42 \mu \mathrm{g} / \mathrm{ml}$, respectively. The developed method could separate the potential degradation products from the analyte peak. Conclusion: The results of validation were found to be satisfactory in all tested validation parameters suggested that the developed method is specific, precise, accurate and robust. Hence, this method would be applied for quantification of paliperidone in bulk and solid dosage form.
\end{abstract}

Key words: Paliperidone, RP-HPLC, Stability of analytical solution, Validation, Stress testing.

\section{INTRODUCTION}

Paliperidone (Figure 1) is a benzisoxazole derivative and it is an active metabolite of risperidone belongs to second generation atypical antipsychotic drug. ${ }^{1}$ Its molecular weight and molecular formula is 426.492 $\mathrm{g} / \mathrm{mol}$ and $\mathrm{C}_{23} \mathrm{H}_{27} \mathrm{FN}_{4} \mathrm{O}_{3}$, respectively. Chemically paliperidone is a 3-[2-[4-(6-fluoro-1,2-benzoxazol-3-yl)piperidin-1-yl] ethyl]-9-hydroxy-2-methyl-6,7,8,9tetrahydropyrido[1,2-a]pyrimidin-4-one. ${ }^{2}$ Paliperidone is formulated as solid and parenteral (long term depot injection) dosage form. It is prescribed for the treatment of acute schizophrenia and schizoaffective disorder. ${ }^{3-5}$

Different analytical methods have been reported in the literature for quantifying paliperidone in API and its marketed formulations, which include UV-visible spectrophotometer, ${ }^{6}$ HPLC with UV detector, ${ }^{7-10}$ UHPLC-MS/MS ${ }^{11}$ and HPTLC. ${ }^{12}$ Among them, most of the reported analytical methods in the literature have either had more retention time, usage of buffers or have tedious analytical procedures which leads to turnout samples were less
Submission Date: 22-02-2019; Revision Date: 17-05-2019; Accepted Date: 04-09-2019

DOI: 10.5530/ijper.53.4s.166 Correspondence:

Dr. Satheesha Babu Birur Kotappa,

Department of Pharmaceutics, Government College of Pharmacy, No.2,

P KalingaRao Road,

Subbaiah Circle,

Bengaluru-560027,

Karnataka, INDIA.

Phone: +91 9481687878

E-mail: bksatishbabu@gmail. com

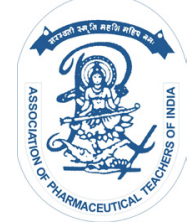

www.ijper.org 


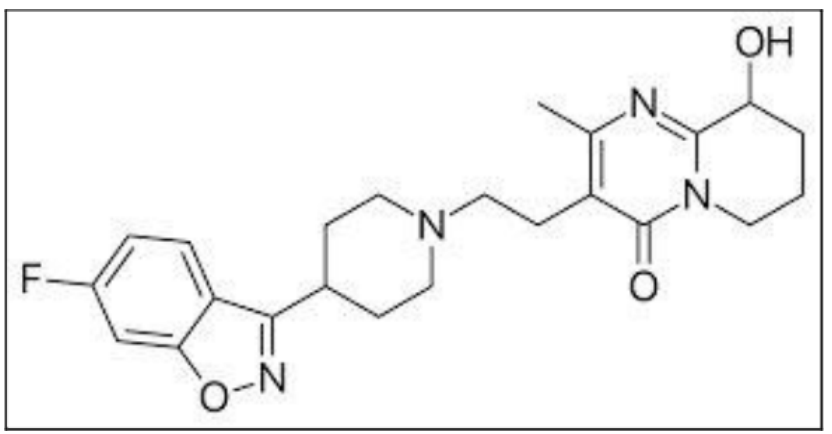

Figure 1: Chemical structure of paliperidone.

thereby the existing method are not economical. The pharmaceutical industry needs an analytical method having lesser retention time and faster analytical procedures with more turnout samples. The stability indicating method is very important parameter to predict the effect of degraded products on peak of a drug. The aim of the present work is to develop a RP-HPLC method for the quantification of paliperidone in bulk and solid dosage form to achieve shorter retention time. Avoiding the usage of buffer during the preparation of the mobile phase involved a weighing procedure where the occurrence of human error may be possible. The proposed method not required the addition of buffer thereby human error may be minimized. The developed method has been validated as per ICH Q2(R1) guidelines $^{13}$ and to study the degradation behavior of paliperidone under a variety of ICH Q1A(R2) ${ }^{14}$ recommended stress conditions like acid and alkaline hydrolysis, oxidation, thermal and photolytic degradation. ${ }^{15,16}$

\section{MATERIALS AND METHODS}

\section{Instrumentation and chromatographic conditions}

A high-performance liquid chromatography instrument (Shimadzu-LC-20AD Prominence, Japan) equipped with Lab Solutions software was used for data acquisition and system suitability parameters calculation. The chromatographic separation was performed on Phenomenex, Gemini NX, ODS column $\left(\mathrm{C}_{18}, 150 \times 4.6\right.$ $\mathrm{mm} 5 \mu \mathrm{m}$ particle size) with the mobile phase composing of methanol, acetonitrile and $0.15 \% \mathrm{v} / \mathrm{v}$ triethylamine in water $(\mathrm{pH} 6)$ in the ratio of 50:20:30 v/v, flow rate was $1 \mathrm{ml} / \mathrm{min}$, UV detection wavelength was found to be $237 \mathrm{~nm}$ and injection volume was $20 \mu \mathrm{l}$.

\section{Chemicals}

Paliperidone working standard (purity 100.3\%) and bulk drug (purity 99.7\%) were obtained from Bal Pharma Limited, Bangalore, India as a gift sample.
Paliperidone (PALIRIS*3 and $6 \mathrm{mg}$ ) extended release tablets were purchased from a local pharmacy. The HPLC grade methanol and acetonitrile used were of Merck specialities Pvt. Ltd. Mumbai, India. Triethylamine, Ortho phosphoric acid, hydrochloric acid, sodium hydroxide and hydrogen peroxide used were analytical grade and purchased from SD Fine Chem Ltd. Mumbai, India. HPLC grade water was prepared using Milli- ${ }^{\circledR}$ Millipore water purification system. Class-A glassware were used throughout the experiments.

\section{Mobile phase preparation}

The mobile phase was a mixture of methanol:acetonitrile: $0.15 \% \mathrm{v} / \mathrm{v}$ triethylamine in water $(\mathrm{pH} 6)$ in the ratio of 70:20:30 v/v, filtered through 0.45 micron finer porosity nylon membrane filter and degassed prior to use. $0.15 \% \mathrm{v} / \mathrm{v}$ triethylamine in water (pH 6) was prepared by mixing $1.5 \mathrm{ml}$ triethylamine in $1000 \mathrm{ml}$ HPLC grade water adjusting $\mathrm{pH} 6.0 \pm 0.05$ with dilute ortho phosphoric acid using calibrated Eutech $\mathrm{pH}$ meter. The mobile phase was selected on the basis of peak purity, peak symmetry, theoretical plate and tailing factor.

\section{Standard and sample preparation}

The primary stock solution of paliperidone was prepared by dissolving $15 \mathrm{mg}$ in a $100 \mathrm{ml}$ volumetric flask containing a $75 \mathrm{ml}$ methanol as a diluent and sonicated for 10 min to dissolve it completely. ${ }^{17}$ The volume was made up to the mark with methanol to get a concentration of $150 \mu \mathrm{g} / \mathrm{ml}$. Further $2 \mathrm{ml}$ from the primary stock solution make up to $10 \mathrm{ml}$ by addition of methanol to get a working standard concentration of $30 \mu \mathrm{g} / \mathrm{ml}$ (secondary stock solution). In the present study, the preparation of the primary and secondary stock solution of paliperidone bulk drug and sample was initially tried with mobile phase as a diluent and the same solution were analyzed in RP-HPLC and we obtained a peak shape was poor since the shape was not homogeneous and peak tailing was also observed. As paliperidone solubility in water was poor $(0.033 \mathrm{mg} / \mathrm{ml})$. Hence water was not chosen as diluent. Further, the solubility of paliperidone was carried out in methanol and acetonitrile individually, this study revealed that solubility of paliperidone in methanol was relatively more than acetonitrile, methanol also got higher elution strength produces consistent peak shape since complete extraction of drug from formulation was achieved during the sample preparation. The absorbance of the secondary stock solution was scanned by using a UV-Visible spectrophotometer in the range of 200 to $400 \mathrm{~nm}$ using methanol as blank. The sample solutions 
were prepared by weighing separately twenty tablets of paliperidone $3 \mathrm{mg}$ and $6 \mathrm{mg}$ and calculated their average weights, tablets were finely powdered by using mortar and pestle. The tablet powder equivalent to $3 \mathrm{mg}$ paliperidone was weighed separately and transferred into a $100 \mathrm{ml}$ volumetric flask containing $75 \mathrm{ml}$ diluent, sonicated for $30 \mathrm{~min}$ with intermittent shaking. Allowed to cool to room temperature and made up the volume with the same diluent to get a concentration of $30 \mu \mathrm{g} / \mathrm{ml}$. Both the solutions were filtered through 0.45 $\mu \mathrm{m}$ nylon membrane (Millipore) syringe filter before injection.

\section{System suitability}

Secondary stock solution $(30 \mu \mathrm{g} / \mathrm{ml})$ was injected into the chromatography as six replicates. The tailing factor and theoretical plate for the paliperidone peak from the first injection should be less than 2 and should not be less than 2000, respectively. The \%RSD for paliperidone peak area from the six replicates calculated should be less than 2 .

\section{Method Validation}

The developed method has been validated as per ICH guidelines for the parameters like specificity, precision (ruggedness), linearity, range, LOD and LOQ, stability of analytical solution, accuracy and robustness.

\section{Specificity}

The specificity test were carried out to measure the analyte response in the presence of interference from the blank (mobile phase/diluent). Specificity was performed by injecting six replicates of mobile phase and diluent into HPLC system to ensure that the proposed method is specific to the analyte.

\section{Forced degradation studies}

Forced degradation studies were performed by subjecting paliperidone pure drug into ICH recommended stress conditions including acid and alkali hydrolysis, oxidative, thermal and photo degradation. Stress testing was performed to measure the degradation behavior of analyte during stability studies.

\section{Acid and alkali hydrolysis}

Five ml of primary stock solution was transferred into two $50 \mathrm{ml}$ volumetric flask. Then the solution was mixed with equal volume of $0.1 \mathrm{~N} \mathrm{HCl}$ and $0.1 \mathrm{~N} \mathrm{NaOH}$ to each volumetric flask. Both the solutions were kept at $80^{\circ} \mathrm{C}$ for $2 \mathrm{~h}$ in a water bath, cooled to room temperature. Then the solution was neutralized with an equal volume of acid or base to that of the previously added.
Then the volume was made up to $50 \mathrm{ml}$ with the diluent to get a final concentration of $30 \mu \mathrm{g} / \mathrm{ml}$.

\section{Oxidative degradation}

Oxidative stress testing was carried by taking $5 \mathrm{ml}$ of primary stock solution into a $50 \mathrm{ml}$ volumetric flask. The contents were then mixed with $5 \mathrm{ml}$ of $3 \%$ hydrogen peroxide solution. The prepared solution was kept at $80^{\circ} \mathrm{C}$ for $2 \mathrm{~h}$ in a water bath and the reaction mixture was allowed to proceed at room temperature with intermittent shaking. Then the volume was made up to $50 \mathrm{ml}$ with the diluent to get a final concentration $30 \mu \mathrm{g} / \mathrm{ml}$.

\section{Thermal degradation}

Bulk drug was exposed to a temperature of $80^{\circ} \mathrm{C}$ for $2 \mathrm{~h}$ in hot air oven. $30 \mathrm{mg}$ of dried powder is weighed and transferred to a $100 \mathrm{ml}$ volumetric flask containing $75 \mathrm{ml}$ diluent dissolve, make up the volume with the same, to get a concentration of $300 \mu \mathrm{g} / \mathrm{ml}, 1 \mathrm{ml}$ of above solution was further diluted to $10 \mathrm{ml}$ with diluent, to get a final concentration of $30 \mu \mathrm{g} / \mathrm{ml}$.

\section{Photolytic degradation}

Five $\mathrm{ml}$ of primary stock solution was exposed to UV light at $254 \mathrm{~nm}$ for $72 \mathrm{~h}$ in UV cabinet. Then the solution volume was made up to $50 \mathrm{ml}$ with the diluent to get a final concentration of $30 \mu \mathrm{g} / \mathrm{ml}$. Injecting the resultant solution of all stress condition samples into HPLC system, record the chromatograms to assess the degradation behavior of bulk drug.

\section{Precision}

The precision is the measurement of repeatability and ruggedness of the analytical method by injecting the six replicates. It is usually expressed as the RSD. The system, method and intermediate precision were carried out to know the developed analytical method is precise. System and method precision was studied by analysing the six replicates and calculated the \%RSD of area counts of bulk drug peak. Intermediate precision (Ruggedness) is the measurement of precision under different sets of condition by injecting six replicates into HPLC system on same day on interval of one $\mathrm{h}$ up to $12 \mathrm{~h}$ (interday analysis), on three consecutive days (intraday analysis), by using different analysts and different instruments. Overall \%RSD for corresponding peak areas under each condition was calculated.

\section{Linearity, Range}

The linearity was established by injecting six replicates at six different concentration levels ranging from 7.5 to $150 \mu \mathrm{g} / \mathrm{ml}$ were prepared from the primary stock solution. The peak area responses were measured in trip- 
licate at all concentrations. The mean peak area count were plotted against the corresponding concentration $(\mu \mathrm{g} / \mathrm{ml})$ to establish calibration curve, calculate the correlation coefficient, slope and intercept using calibration curve (acceptance criterion for correlation coefficient shall not be less than 0.997).

\section{LOD and LOQ}

The LOD and LOQ values of the developed method were obtained based on the standard deviation of the peak response and its slope as per ICH guidelines. This method involves the construction of the calibration curve from which slope and intercept were obtained. The standard deviation of the peak response was calculated by repeated injection of different concentration of drug solution to determine the standard deviation of intercepts of the regression line. Further, the LOD and LOQ of the developed method were obtained by the formula: $\mathrm{LOD}=3.3 \times(\sigma / \mathrm{S})$ and $\mathrm{LOQ}=10 \times(\sigma / \mathrm{S})$, where, $\sigma=$ Standard deviation of the peak response of calibration curve and $\mathrm{S}=$ Slope of the calibration curve, respectively.

\section{Stability of analytical solution}

The previously prepared secondary stock solution and sample solution $(30 \mu \mathrm{g} / \mathrm{ml})$ were kept in room temperature. Both the solutions were analyzed at time intervals of 0,24 and $48 \mathrm{~h}$. The average \%RSD of area counts for the standard and sample solution was calculated.

\section{Accuracy}

The accuracy study was performed to determine the recovery of known amounts of paliperidone drug added to the sample by spiking a known amount of standard in to sample at three different concentration levels $(75 \%$, $100 \%$ and $125 \%$ ), in triplicate. Six replicates of each set in each concentration level were analysed by developed method and the amount of paliperidone recovered was calculated. Individual and overall \%RSD of area counts and \%recovery of the analyte shall be less than 2 .

\section{Robustness}

The robustness of the analytical method was determined by varying the analytical procedures such as flow rate, detection wavelength, mobile phase composition and $\mathrm{pH}$ of buffer solution to measure the capacity of the analytical method at the deliberate changes in instrumental conditions. The flow rate was changed from $1 \mathrm{ml} / \mathrm{min}$ to $0.9 \mathrm{ml} / \mathrm{min}$ and $1.1 \mathrm{ml} / \mathrm{min}$, detection wavelength was changed from $237 \mathrm{~nm}$ to $235 \mathrm{~nm}$ and $239 \mathrm{~nm}$, The mobile phase ratio was varied from $50: 20: 30 \mathrm{v} / \mathrm{v}$ to $45: 25: 30 \mathrm{v} / \mathrm{v}$ and 55:15:30 v/v and $\mathrm{pH}$ of the buffer solution was changed from 6.0 to 5.8 and 6.2. System suitability parameters were checked in each variable condition. \%RSD of area counts and \%amount of drug recovered were calculated in each case (acceptance criterion: overall \%RSD shall not be more than 2 and $\%$ amount recovered \pm 10 ).

\section{Assay of paliperidone in tablets}

The assay of paliperidone tablets was performed by the following method. 20 tablets of paliperidone from each product (PALIRIS*3 $\mathrm{mg}$ and $6 \mathrm{mg}$ ) were weighed and their average weight was calculated, tablets were finely powdered in a mortar by a pestle. From the total tablet powder, the powder weight correspondence to equivalent to $3 \mathrm{mg}$ of paliperidone was weighed and extracted the drug into methanol by sonicating for $30 \mathrm{~min}$ finally the volume was adjusted to $100 \mathrm{ml}$ by addition of methanol. The resulting solution was filtered through a $0.45 \mu \mathrm{m}$ nylon membrane (Millipore) filter. The filtered solution of $20 \mu \mathrm{l}$ was injected to get the chromatogram. The percentage amount of drug present per tablet was calculated.

\section{RESULTS AND DISCUSSION}

\section{Method development}

The absorption maximum $(\lambda \max )$ of paliperidone in methanol was found to be $237 \mathrm{~nm}$. This wavelength is selected as a detection wavelength in the method development and validation process. The chromatographic condition was finalized by various trials by changing various parameters, such as appropriate column, (dimension, type of stationary phase, bonding technology and particle size) mobile phase composition and $\mathrm{pH}$ used in mobile phase to achieve short analysis time, sharp peak, maximum theoretical plate with minimum tailing factor. The retention time, separation of peak and peak shape were dependent on the $\mathrm{pH}$ of the buffer solution and the percentage of methanol and acetonitrile in mobile phase. Different stationary and mobile phases were tried but satisfactory separation with short retention time and good symmetrical peak were achieved with mobile phase consisting of methanol, acetonitrile and $0.15 \% \mathrm{v} / \mathrm{v}$ triethylamine in water $(\mathrm{pH}$ 6) in the ratio 50:20:30 v/v with Phenomenex, Gemini NX, ODS column $(150 \times 4.6 \mathrm{~mm}, 5 \mu \mathrm{m}$, particle size) used as a stationary phase within a short analysis time of $7 \mathrm{~min}$. The mobile phase selection depicts the less possibilities of variation compared to methods with liquid buffers where weighing of ingredients are involved as a part of the mobile phase preparation procedure. A typical chromatogram obtained by using 


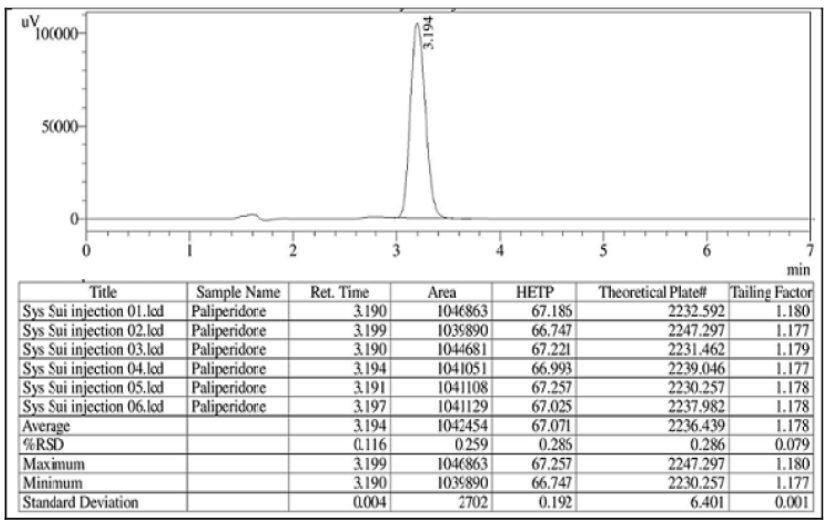

Figure 2: Typical chromatograph of paliperidone.

the above mentioned mobile phase is illustrated in Figure 2. Paliperidone had a short retention time of 3.2 min. No blank peak was observed at the retention time of the analyte peak.

\section{System suitability}

Using the system suitability software, retention time, theoretical plates and tailing factor for paliperidone peak were obtained and \%RSD for six replicates was calculated. The retention time, tailing factor and theoretical plates for the paliperidone from the six replicates was found to be $3.194 \pm 0.004 \mathrm{~min}, 1.178 \pm 0.001$ and $2236.439 \pm 6.401$, respectively. \%RSD for tailing factor, theoretical plates and peak area count for the paliperidone was found to be $0.116,0.079,0.286$ and 0.259 , respectively. The above three system suitability parameters tailing factor, theoretical plate number and \%RSD were met during the course of entire validation.

\section{Method validation \\ Specificity}

The result of interference study indicates that there are no co-eluting peaks from blank, mobile phase and stress conditions indicate that the paliperidone peak is homogeneous.

\section{Forced Degradation Studies}

In forced degradation studies, the paliperidone was found to be degrading in alkaline and thermal stress condition. The paliperidone solution in alkaline hydrolysis stress condition showed $6.22 \%$ degradation and degradation peaks were eluted at 1.89 and $5.51 \mathrm{~min}$. Paliperidone pure drug in thermal stress condition was observed $8.57 \%$ degradation and degradation peak was eluted at $2.50 \mathrm{~min}$. Minor degradation observed in photolytic stress condition showed $1.248 \%$ and degradation peak was observed at 2.179 min. No degradation peaks were observed in acid hydrolysis and oxidative

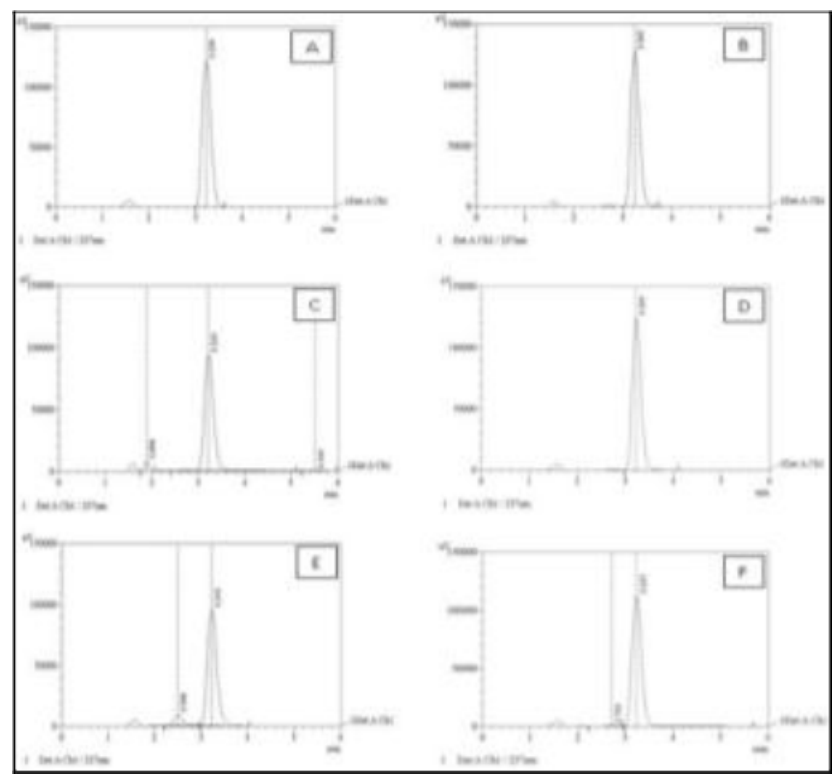

Figure 3: Forced degradation studies of paliperidone under various stress condition.

Chromatographs showing standard paliperidone (A), acid degradation $(0.1 \mathrm{~N} \mathrm{HCl})$ studies $(B)$, basic degradation $(0.1 \mathrm{~N} \mathrm{NaOH})$ studies $(C)$, oxidative degradation $(D)$, thermal degradation $(E)$ and photolytic degradation studies (F) for paliperidone.

degradation. Typical chromatograms of bulk druginnormal condition and different stress conditions are shown in Figure 3. Results of forced degradation study stated that the paliperidone peak is homogenous, pure and unaffected even in the presence of its degradation products, confirming the stability indicating nature of the method. Hence, the developed method is able to determine paliperidone in the presence of its degradation products.

\section{Precision}

For precision study, the results of individual and overall $\%$ RSD should be less than 2 for precision, which was achieved successfully. The system and method was found to be precise as the $\%$ RSD of the area counts for six replicates was 0.283 and 0.394 , respectively. In intermediate precision, individual \%RSD of amount present for paliperidone was found to be less than $2 .{ }^{18,19}$ Hence, the developed method is rugged. The results are given in Table 1.

\section{Linearity, Range}

The regression equation from peak response versus concentration data (Figure 4) obtained $y=34255 x+21521$, correlation coefficient $\left(r^{2}\right)$ was 0.999 and percentage curve fitting was $99.9 \%$ indicating that the response is linear over the specified range of $7.5-150 \mu \mathrm{g} / \mathrm{ml}$. 


\begin{tabular}{|c|c|c|c|c|c|c|c|c|c|c|c|}
\hline \multirow[b]{3}{*}{ 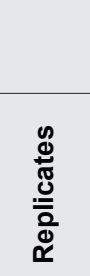 } & \multirow{3}{*}{$\begin{array}{c}\begin{array}{c}\text { System } \\
\text { precision }\end{array} \\
\text { Peak } \\
\text { Area }\end{array}$} & \multirow{3}{*}{$\begin{array}{c}\begin{array}{c}\text { Method } \\
\text { precision }\end{array} \\
\text { Peak Area }\end{array}$} & \multicolumn{9}{|c|}{ Intermediate precision (ruggedness) } \\
\hline & & & \multicolumn{2}{|c|}{ Intraday } & \multicolumn{2}{|c|}{ Interday } & \multirow[b]{2}{*}{ 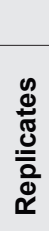 } & \multirow{2}{*}{$\begin{array}{c}\text { Analyst } 1 \\
\text { Peak } \\
\text { Area }\end{array}$} & \multirow{2}{*}{$\begin{array}{c}\text { Analyst } 2 \\
\\
\text { Peak } \\
\text { Area }\end{array}$} & \multirow{2}{*}{$\begin{array}{c}\text { Instrument-1 } \\
\text { Peak Area }\end{array}$} & \multirow{2}{*}{$\begin{array}{c}\text { Instrument-2 } \\
\text { Peak Area }\end{array}$} \\
\hline & & & $\begin{array}{c}\text { Time } \\
\text { interval } \\
\text { (in h) }\end{array}$ & $\begin{array}{l}\text { Mean } \\
\text { Peak } \\
\text { Area }\end{array}$ & Day & $\begin{array}{l}\text { Mean } \\
\text { Peak } \\
\text { Area }\end{array}$ & & & & & \\
\hline 1 & 1044004 & 1045079 & 1 & 1059017 & 1 & 1039104 & 1 & 1045780 & 1049010 & 1057956 & 1009162 \\
\hline 2 & 1048190 & 1044100 & 2 & 1066249 & 2 & 1041721 & 2 & 1040540 & 1042152 & 1058138 & 1018417 \\
\hline 3 & 1044994 & 1034534 & 3 & 1065569 & 3 & 1049862 & 3 & 1034841 & 1050613 & 1055928 & 1020224 \\
\hline 4 & 1041068 & 1044227 & 4 & 1053540 & & & 4 & 1045370 & 1050519 & 1054924 & 1016637 \\
\hline 5 & 1040134 & 1040252 & 5 & 1056657 & & & 5 & 1044311 & 1049995 & 1049384 & 1009460 \\
\hline \multirow{2}{*}{6} & \multirow{2}{*}{1042094} & \multirow{2}{*}{1044601} & 6 & 1057956 & & & \multirow{2}{*}{6} & \multirow{2}{*}{1037944} & \multirow{2}{*}{1048671} & \multirow{2}{*}{1054735} & \multirow{2}{*}{1014223} \\
\hline & & & 12 & 1038079 & & & & & & & \\
\hline Mean & 1043414 & 1042132 & & 1056724 & & 1043562 & & 1041464 & 1048493 & 1057341 & 1014687 \\
\hline SD & 2954.96 & 4106.26 & & 9429.68 & & 5610.39 & & 4451.93 & 3205.07 & 1097.27 & 4613.81 \\
\hline$\%$ RSD & 0.283 & 0.394 & & 0.892 & & 0.538 & & 0.427 & 0.306 & 0.104 & 0.455 \\
\hline
\end{tabular}

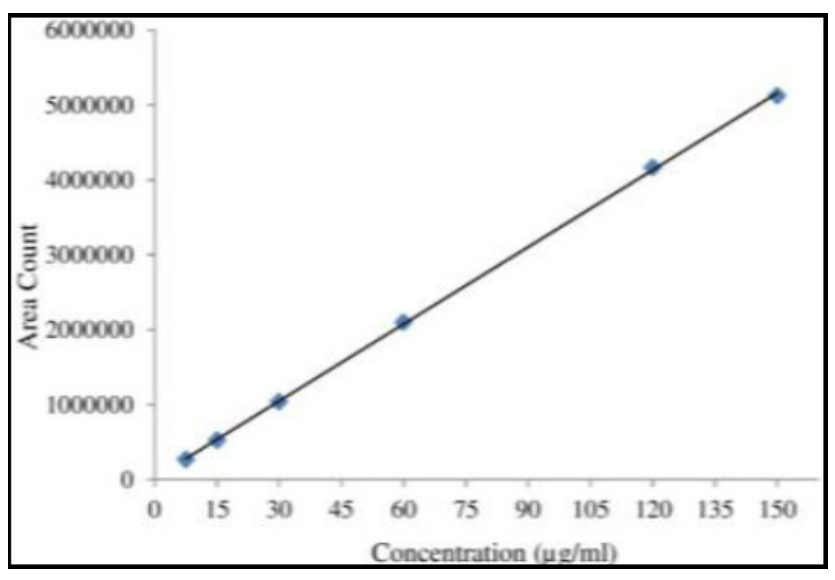

Figure 4: Standard calibration curve of paliperidone $\left(y=34255 x+21521, R^{2}=0.999\right)$.

\section{LOD and LOQ}

The detection and quantification limits for paliperidone was found to be $0.14 \mu \mathrm{g} / \mathrm{ml}$ and $0.42 \mu \mathrm{g} / \mathrm{ml}$, respectively.

\section{Stability of analytical solution}

The stability of the standard solution the cumulative $\%$ RSD was found to be $0.69 \%$ and in sample solution the cumulative $\%$ RSD was found to be $0.97 \%$. As the cumulative $\%$ RSD of standard and sample solution of paliperidone is within the acceptable limits (\%RSD shall be less than $2.0 \%$ ). It reveals that standard and sample solutions are stable up to $48 \mathrm{~h}$ at room temperature.

\section{Accuracy}

The recovery studies of analyte at each level was examined and ranged from $100.148 \%$ to $101.289 \%$. As percentage recovery is found within the acceptance limits, ${ }^{19,20}$ also individual and overall \%RSD was calculated and it was found within the acceptance limits, the high value of recoveries obtained for paliperidone indicate that the developed method is accurate. Results are shown in Table 2.

\section{Robustness}

In all the deliberate varied chromatographic conditions (flow rate, wavelength of detection, concentration of organic solvents and $\mathrm{pH}$ of buffer solution) the results obtained were well within the limits. The robustness data of paliperidone have been incorporated in Table 3, which proves the robustness of the method.

\section{Assay of paliperidone in tablets}

Two batches of different strength tablets were analysed using developed method. Satisfactory results were obtained with the label claim. The percentage assay of paliperidone in marketed formulation was found to be $104.37 \%$ for PALIRIS ${ }^{\circledR} 3$ and $98.82 \%$ for PALIRIS ${ }^{\circledR} 6$ tablets. The results show that there is no interference of excipients and impurities were observed in samples for the developed method. 


\begin{tabular}{|c|c|c|c|c|c|c|c|c|}
\hline $\begin{array}{l}\text { Level } \\
(\%)\end{array}$ & Replicate & $\begin{array}{l}\text { Sample } \\
\text { Conc. } \\
(\mu \mathrm{g} / \mathrm{ml})\end{array}$ & $\begin{array}{l}\text { Standard } \\
\text { Conc. } \\
\text { ( } \mu \mathrm{g} / \mathrm{ml})\end{array}$ & $\begin{array}{c}\text { Mean } \\
\text { Peak Area }\end{array}$ & $\begin{array}{l}\text { Amt. of standard } \\
\text { recovered }(\mu \mathrm{g} / \\
\mathrm{ml})\end{array}$ & $\%$ Recovery & $\begin{array}{l}\text { Mean \% } \\
\text { Recovery }\end{array}$ & $\begin{array}{l}\text { Mean } \\
\text { \%RSD }\end{array}$ \\
\hline \multirow{3}{*}{75} & 1 & 15 & 7.5 & 781275 & 7.484 & 99.783 & \multirow{9}{*}{100.643} & \multirow{3}{*}{0.948} \\
\hline & II & 15 & 7.5 & 786127 & 7.623 & 101.645 & & \\
\hline & III & 15 & 7.5 & 782764 & 7.527 & 100.354 & & \\
\hline \multirow{3}{*}{100} & I & 15 & 15 & 1046097 & 15.105 & 100.699 & & \multirow{3}{*}{0.481} \\
\hline & II & 15 & 15 & 1043031 & 15.017 & 100.111 & & \\
\hline & III & 15 & 15 & 1041114 & 14.961 & 99.743 & & \\
\hline \multirow{3}{*}{125} & I & 15 & 22.5 & 1309842 & 22.695 & 100.866 & & \multirow{3}{*}{0.521} \\
\hline & II & 15 & 22.5 & 1311824 & 22.752 & 101.120 & & \\
\hline & III & 15 & 22.5 & 1317794 & 22.923 & 101.880 & & \\
\hline
\end{tabular}

* Mobile phase- methanol, acetonitrile and $0.15 \% \mathrm{v} / \mathrm{v}$ triethylamine in water ( $\mathrm{pH} 6$ ) in the ratio of (70:20:30 v/v); flow rate-1.0 ml/min; column-Phenomenex, Gemini NX, $\mathrm{C}_{18}$; Detection wavelength $237 \mathrm{~nm}$; injection volume $20 \mu \mathrm{l}$.

\begin{tabular}{|c|c|c|c|c|c|c|c|c|c|}
\hline \multirow[t]{2}{*}{ Parameters } & \multirow{2}{*}{$\begin{array}{l}\text { Normal } \\
\text { condition * }\end{array}$} & \multicolumn{2}{|c|}{$\begin{array}{l}\text { Flow rate } \\
( \pm 0.1 \mathrm{ml} / \mathrm{min})\end{array}$} & \multicolumn{2}{|c|}{$\begin{array}{l}\text { Wavelength } \\
( \pm 2 \mathrm{~nm})\end{array}$} & \multicolumn{2}{|c|}{$\begin{array}{l}\text { Conc. of organic } \\
\text { solvent }( \pm 5 \mathrm{v} / \mathrm{v})\end{array}$} & \multicolumn{2}{|c|}{$\begin{array}{l}\mathrm{pH} \text { of buffer solution } \\
( \pm 0.2)\end{array}$} \\
\hline & & 0.9 & 1.1 & 235 & 239 & $45: 25: 30$ & $55: 15: 30$ & pH 5.8 & pH 6.2 \\
\hline Amount (\%) & 100.111 & 108.903 & 95.731 & 100.409 & 98.671 & 99.678 & 99.770 & 100.675 & 100.418 \\
\hline RSD (\%) & 0.393 & 0.161 & 0.094 & 0.132 & 0.139 & 0.314 & 0.196 & 0.347 & 0.836 \\
\hline $\begin{array}{l}\text { Retention } \\
\text { time (min) }\end{array}$ & 3.198 & 3.479 & 2.857 & 3.131 & 3.128 & 2.930 & 2.931 & 3.094 & 3.082 \\
\hline $\begin{array}{l}\text { Tailing } \\
\text { factor }\end{array}$ & 1.179 & 1.186 & 1.174 & 1.174 & 1.173 & 1.167 & 1.166 & 1.167 & 1.171 \\
\hline $\begin{array}{l}\text { Theoretical } \\
\text { plate \# }\end{array}$ & 2213.03 & 2157.58 & 2018.69 & 2067.57 & 2070.25 & 2166.98 & 2163.12 & 2073.76 & 2169.06 \\
\hline
\end{tabular}

\section{CONCLUSION}

Stability-indicating RP-HPLC method was developed for the quantification of paliperidone in bulk and marketed solid dosage form. The developed RP-HPLC method was validated as stated in the ICH guidelines and obtained validation results were found to be satisfactory in all the tested parameters suggested that the method become simple, rapid, accurate and precise. The developed method is economical with shorter retention time of $3.2 \mathrm{~min}$ due to this the method require less time, thereby the consumption of the mobile phase is less and analyse more number of samples in shorter period of time. The results of the forced degradation study suggested that the method is specific. No other co-eluting peak was observed at the retention time of paliperidone peak. The result of stability of analytical solution reveals that there is no special precaution to be taken during the preparation and analysis of sample because the solutions of standard and sample were stable at room temperature up to $48 \mathrm{~h}$. Hence, the developed method can be conveniently used for determining the quality control of paliperidone in bulk drug and solid dosage form.

\section{ACKNOWLEDGEMENT}

The authors are thankful to M/s BAL Pharma Limited, Bangalore, Karnataka, India for providing a gift samples of working reference standard and bulk drug of paliperidone with certificate of analysis.

\section{CONFLICT OF INTEREST}

The authors declare no conflicts of interest.

\section{ABBREVIATIONS}

RP-HPLC: Reverse Phase High Performance Liquid Chromatography; RSD: Relative Standard Deviation; ICH: International Conference on Harmonization; LOD: Limit of Detection; LOQ: Limit of Quantification; UHPLC-MS/MS: Ultra-High Performance Liquid Chromatography Tandem Mass Spectrometry; UV: Ultra Violet; ODS: Octadecyl silane; HCl: Hydrochloric acid; $\mathbf{N a O H}$ : Sodium Hydroxide; $\mathbf{H}_{2} \mathbf{O}_{2}$ : Hydrogen Peroxide; SD: Standard Deviation. 


\section{REFERENCES}

1. Sweetman SC. Martindale: The complete drug reference, $36^{\text {th }}$ ed. London: Pharmaceutical Press, The Royal Pharmaceutical Society. 2009.

2. Canuso CM, Youssef EA, Bossie CA, Turkoz I, Schreiner A, Simpson GM. Paliperidone extended-release tablets in schizophrenia patients previously treated with risperidone. Int Clin Psychopharmcol. 2008;23(4):209-15.

3. Fowler JA, Bettinger TL, Argo TR. Paliperidone extended release tablets for the acute and maintenance treatment of schizophrenia. Clin Ther. 2008;30(2):231-48.

4. Dolder C, Nelson M, Deyo Z. Paliperidone for schizophrenia. Am J Health Syst Pharm. 2008;65(5):403-13.

5. Tianmei S, Liang S, Yi L, Yun'Ai S, Chunmei G, Hongyan Z. Single-dose pharmacokinetics of Paliperidone extended release tablets in healthy Chinese subjects. Hu Psychopharmacol: Clin Experim. 2010;25(5):404-9.

6. Manjuladevi AS, Ravi TK. A Validated RP-HPLC Method for the Estimation of Paliperidone in Bulk and Tablet Dosage Form. Am J Pharm Tech Res. 2012;2(3):616-26

7. Swarnalatha G, Vijayakumar B, Jothieswari D, Reddy PJ, Mohankumar M Method development and validation of RP-HPLC method for determination of new antipsychotic agent in paliperidone palmitate bulk drug. Int $\mathrm{J}$ Novel Trends Pharm Sci. 2014;4(4):101-10.

8. Sherje AP, Londhe V. Stability indicating HPLC method for determination of paliperidone in bulk. Int J PharmTech Res. 2015;8(8):157-63.

9. Bindu KH, Reddy IU, Anjaneyulu Y, Suryanarayana MV. A stability-indicating ultra-performance liquid chromatographic method for estimation of related substances and degradants in paliperidone active pharmaceutical ingredient and its pharmaceutical dosage forms. J Chromatogr Sci. 2012;50(4):368-72.

10. Chen H, Zhao L, Li G, Leng D, Ma P, Tong L, et al. Development and validation of a rapid and sensitive UHPLC-MS/MS method for the determination of paliperidone in beagle dog plasma. Asian J Pharm Sci. 2014;9(5):286-92.

11. Pawar SM, Dhaneshwar SR. Validated High Performance Thin Layer Chromatographic Method for Quantitation of Paliperidone in the Presence of

\section{PICTORIAL ABSTRACT}

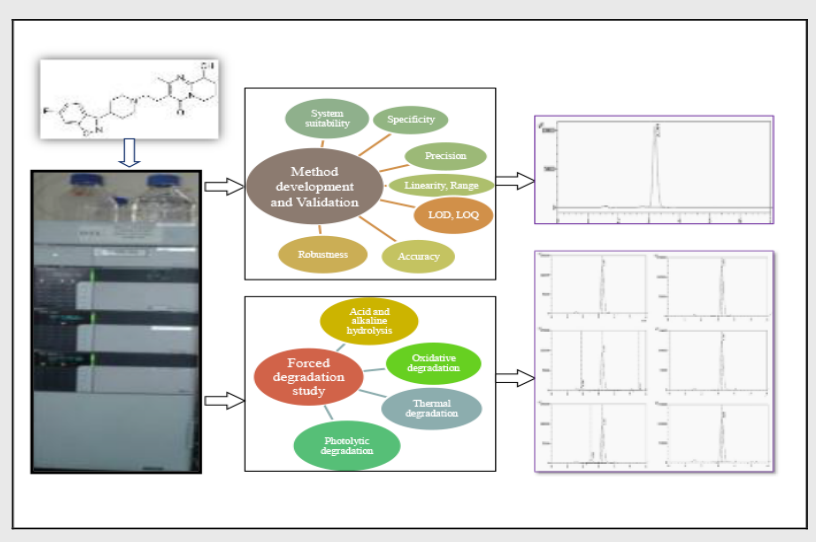

Degradation Products Formed under ICH Recommended Stress Condition. J Pharm Biomed Sci. 2012;16(15):17-26.

12. Rele RV. Spectrophotometric Estimation of Paliperidone in Bulk Drug and Pharmaceutical Dosage Form by Area Under Curve Method. Res J Pharm Tech. 2017;10(1):31-4.

13. ICH: Validation of Analytical Procedures: Text and Methodology Q2(R1) International Conference on Harmonization. 2005.

14. ICH: Stability Testing of New Drug Substances and Products $\mathrm{Q} 1 \mathrm{~A}(\mathrm{R} 2)$. International Conference on Harmonization. 2003.

15. Blessy M, Patel RD, Prajapati PN, Agrawal YK. Development of forced degradation and stability indicating studies of drugs—A review. J Pharm Anal. 2014;4(3):159-65.

16. Vamsi KM, Rajendra ND, Jalachandra $R$, Venugopal $P$, Sandeep $P$, Madhavi G. Quality by Design (QbD) approach to develop HPLC method for eberconazole nitrate: Application to hydrolytic, thermal, oxidative and photolytic degradation kinetics. J Saudi Chem Soc. 2016;20(Suppl 1):S313-22.

17. Atila KS, Yeniceli UD. Chemometrically assisted optimization and validation of a new HPLC method for the determination of paliperidone in pharmaceuticals. J Liq Chromatogr Relat Technol. 2018;41(3):129-34.

18. Alquadeib BT. Development and validation of a new HPLC analytical method for the determination of diclofenac in tablets. Saudi Pharm J. 2019;27(1):66-70.

19. Shabir GA. Step-by-step analytical methods validation and protocol in the quality system compliance industry. Institute of Validation Technology: Analytical Methods Validation. Advanstar Communications Inc. Duluth. 2006;4-14.

20. Bansal R, Chandrabose K, Moorthy NH, Singh DP, Singh D, Trivedi P. A new simple and rapid validated RP-HPLC method for determination of ziprasidone in ziprasidone capsules. J Saudi Chem Soc. 2016;20(Suppl 1):S161-7.

21. Naseef H, Moqadi R, Qurt M. Development and validation of an HPLC method for determination of antidiabetic drug alogliptin benzoate in bulk and tablets. $J$ Anal Methods Chem. 2018;1-7.

\section{SUMMARY}

A simple, rapid, accurate and precise stability indicating RP-HPLC method was developed validated and forced degradation studies were carried out as per the ICH guidelines to determination of the paliperidone in bulk and solid dosage forms. The developed method requires less time and the consumption of the mobile phase was also less due to reduction in retention time. During forced degradation study results were suggested the developed method is specific and there was an absence of other co-eluting peaks along with the specific peak of paliperidone suggested that the developed method could be used for quantifying paliperidone in bulk drug and its tablets.

\section{About Authors}

Sadashivaiah Rudragangaiah, M. Pharm: Currently pursuing Ph.D (Pharmaceutics) at Government College of Pharmacy, \#2, P Kalinga Rao Road, Subbaiah Circle, Bengaluru, Karnataka, India. His research area is analytical method development, validation and novel drug delivery systems.

Rohith Ganapathi Bhatta, M. Pharm: Currently pursuing Ph.D (Pharmaceutics) at Government College of Pharmacy, \#2, P Kalinga Rao Road, Subbaiah Circle, Bengaluru, Karnataka, India. His research area is analytical method development, validation and novel drug delivery systems.

Dr. Satheeshababu Birur Kotappa, M. Pharm, Ph.D: Presently working as a Associate Professor at Department of Pharmaceutics, Government College of Pharmacy, \#2, P Kalinga Rao Road, Subbaiah Circle, Bengaluru, Karnataka, India. His research area is novel drug delivery systems.

Cite this article: Sadashivaiah R, Rohith GB, Satheeshababu BK. Stability-Indicating RP-HPLC Method for the Quantification of Paliperidone in Bulk and Solid Dosage Form to Establish Validation and Stability Indicating Parameters. Indian J of Pharmaceutical Education and Research. 2019;53(4s):s691-s698. 